


\section{Computational Vision and Medical Image Processing V}

Editors

João Manuel R.S. Tavares \& R.M. Natal Jorge

Faculdade de Engenharia, Universidade do Porto, Porto, Portugal 
CRC Press/Balkema is an imprint of the Taylor \& Francis Group, an informa business

(C) 2016 Taylor \& Francis Group, London, UK

Typeset by V Publishing Solutions Pvt Ltd., Chennai, India

Printed and bound in Great Britain by CPI Group (UK) Ltd, Croydon, CR0 4YY

All rights reserved. No part of this publication or the information contained herein may be reproduced, stored in a retrieval system, or transmitted in any form or by any means, electronic, mechanical, by photocopying, recording or otherwise, without written prior permission from the publisher.

Although all care is taken to ensure integrity and the quality of this publication and the information herein, no responsibility is assumed by the publishers nor the author for any damage to the property or persons as a result of operation or use of this publication and/or the information contained herein.

Published by: CRC Press/Balkema

P.O. Box 11320, 2301 EH Leiden, The Netherlands

e-mail: Pub.NL@taylorandfrancis.com

www.crcpress.com - www.taylorandfrancis.com

ISBN: 978-1-138-02926-2 (Hbk)

ISBN: 978-1-315-64279-6 (eBook PDF) 


\section{Table of contents}

Acknowledgements $\quad$ ix

Preface $\quad$ xi

Invited lectures xiii

Scientific committee $\quad$ XV

Invited lectures

An adaptive non-rigid image registration technique using hierarchical B-splines

A. Pawar, Y. Zhang, X. Wei, Y. Jia, T. Rabczuk, C.L. Chan \& C. Anitescu

Medical image segmentation using Object Shape Models: A critical review on recent trends, and alternative directions

A.X. Falcão, T.V. Spina, S.B. Martins \& R. Phellan

Primal-dual method for continuous max-flow approaches

K. Wei, X.-C. Tai, T.F. Chan \& S. Leung

Image restoration using variational approaches: Some recent advances

A. Lanza, S. Morigi \& F. Sgallari

Virtual and augmented medical imaging environments: Applications to simulation, training, surgical planning and interventional guidance

C.A. Linte

\section{Contributed papers}

The fast method of creating High Dynamic Range image for fluorescent microscopy applications

A. Bal

Automatic cheek detection in digital images

M. Frackiewicz, H. Palus \& K. Radlak

A variational model for image fusion with simultaneous cartoon and texture

decomposition

M. Dodangeh, I.N. Figueiredo \& G. Gonçalves

Image contrast enhancement using split Bregman method

S. Gh. Bardeji, I.N. Figueiredo \& E. Sousa

Extraction of spectral drowsy component from the resting electroencephalographic signal for quick, objective and direct testing of sleepiness in absolute terms

A.A. Putilov, O.G. Donskaya \& E.G. Verevkin

The illusion of a blackbody at the human ear and the human temperature measurement

A. Cardoso

Video-based Turkish Sign Language recognition systems

M. Aktaş \& E. B. Sonmez 
A nonsmooth nonconvex sparsity-promoting variational approach for deblurring images corrupted by impulse noise

A. Lanza, S. Morigi \& F. Sgallari

Classification-based blood vessel segmentation in retinal images

J. Odstrcilik, R. Kolar, V. Harabis \& R. P. Tornow

Line extraction via phase congruency with a novel adaptive scale selection for Poisson

noisy images

V.A. Krylov \& J.D.B. Nelson

Diagnosis of human intestinal parasites by deep learning

A.Z. Peixinho, S.B. Martins, J.E. Vargas, A.X. Falcão, J.F. Gomes \& C.T.N. Suzuki

Texture-energy features for microaneurysms detection

D. Veiga, N. Martins, C. Pereira, M. Ferreira \& J. Monteiro

An iterative algorithm for Total Variation minimization in DBT imaging

A.M. Mota, N. Matela, N. Oliveira \& P. Almeida

No-reference wavelet based Retinal Image Quality Assessment

L.S. Abdel Hamid, A. El-Rafei, S. El-Ramly, G. Michelson \& J. Hornegger

Vessel segmentation of retinal images with fuzzy morphology

P. Bibiloni, M. González-Hidalgo \& S. Massanet

Identification of subendocardial infarction - a feasibility study using synthetic ultrasonic image data of a left ventricular model

J. Żmigrodzki, S. Cygan, B. Leśniak-Plewińska \& K. Katużyński

Microcalcification segmentation in full field digital mammography

N. Martins, D. Veiga, C. Pereira, M. Ferreira, N. Alves \& M. Delgado

Unsupervised delineation of the vessel tree in retinal fundus images

N. Strisciuglio, M. Vento, G. Azzopardi \& N. Petkov

A registration algorithm for microscopy images of the capillary bed

H. Rieiro, J.L. Alba Castro, S. Martinez-Conde \& S.L. Macknik

Bilateral filtering based biomedical image colorization

A. Popowicz \& B. Smolka

Comparison of the internal structures of bones by microtomography

J.C.L. Stutz, J.S. Dominguez \& J.T. de Assis

Model adaptation for mesh generation of biological structures

A. Ramos-de-Miguel, R. Montenegro \& J.M. Escobar

Medical volume rendering based on gradient information

T.F. de Moraes, P.H.J. Amorim, J.V.L. da Silva, H. Pedrini, M.I. Meurer

Chaos theory-based quantification of ROIs for mammogram classification

J. Kurek, B. Świderski, S. Dhahbi, M. Kruk, W. Barhoumi, G. Wieczorek \&

E. Zagrouba

M5L: A web-based Computer Aided Detection system for automated search of lung nodules in thoracic Computed Tomography scans

A. Traverso, M. Agnello, P. Cerello, M. Saletta, S. Bagnasco, C. Peroni, E. Fiorina,

M.E. Fantacci, A. Retico \& E. Lopez Torres

Non-intrusive and calibration free visual exploration analysis in children with Autism

Spectrum Disorder

D. Cazzato, F. Adamo, G. Palestra, G. Crifaci, P. Pennisi, G. Pioggia, L. Ruta,

M. Leo \& C. Distante

Semi-automatic tumor contouring method using PET and MRI medical images

S. Urbán, L. Ruskó \& A. Nagy 
Automatic detection of bones based on the confidence map for Rheumatoid Arthritis analysis

K. Radlak, N. Radlak \& B. Smolka

Improved computer recognition of Fuhrman grading system in analysis

of Clear-Cell Renal Carcinoma

M. Kruk, J. Kurek, S. Osowski \& R. Koktysz

A proof of concept of an augmented reality system for Nuss surgery

A. Ferreira, P. Morais, S. Queirós, F. Veloso, N.F. Rodrigues,

J. Correira-Pinto \& J.L. Vilaça

Usage of mobile devices in a bone fracture reduction process

J.R. Jiménez, F. Paulano, J.M. Noguera \& J.J. Jiménez

Automated peritumoral edema segmentation in preoperative brain MRI scans

E. Binaghi, P. Melchiorre, L. Romitelli, S. Balbi \& D. Lattanzi

Evaluation of segmentation techniques for wound area identification

G. Zhang, P. Xiberta, A. Bardera, I. Boada \& A. Romero

Automated image segmentation based on multiobjective optimization and machine

learning

S.M. Shontz, J.S. Tahara, D.O. McLaurin, D.J.L. Colbry \& B. Parikh

Fractal descriptor on holographic images of cervical cells

M. Mihailescu, E.I. Scarlat, I. A. Paun, I. Grigorescu, R. Radu \& O.T. Nedelcu

An integrated two Time-of-Flight camera system to determine knee flexion movement:

Comparison with standard motion analysis system

E. Veron-Tocquet, V. Burdin, J. Savéan, J. Leboucher \& O. Rémy-Néris

Mechanics-based analysis of the left atrium via echocardiographic imaging

S. Gabriele, L. Teresi, V. Varano, P. Nardinocchi, P. Piras, G. Esposito,

P.E. Puddu, C. Torromeo \& A. Evangelista

A new thick-walled conical model of the Left Ventricle

B. Leśniak-Plewińska, S. Cygan, J. Żmigrodzki \& K. Katużyński

Augmented Reality in radiofrequency ablation of the liver tumors

L.T. De Paolis \& F. Ricciardi

Anthropomorphic robot forefinger virtually simulated

H.J. Rabiela, B.V. González \& G.D.A. Miranda

CT based identification problem for the multicompartment model of blood perfusion

E. Rohan, V. Lukeš \& J. Brašnová

A study on discrimination of SIFT feature applied to binary images

Time-constrained detection of colored objects on raw Bayer data

Image scanning techniques for speeded-up color object detection

A. Trifan, A.J.R. Neves \& B. Cunha

Improving deep neural networks classification by preprocessing images

H. Erdmann, F.T. Ito, D. Takabayashi \& D.N. dos Santos

Surface reconstruction of bone fragments: A comparative study

F. Paulano, J.J. Jiménez \& J.R. Jiménez

Towards a robust patch based multi-view stereo technique for textureless and occluded

$3 \mathrm{D}$ reconstruction

B. Haines \& L. Bai 
Forming tool inspection using fiber-optic sensor heads

S. Matthias, M. Kästner, E. Reithmeier, P. Sieczkarek \& A.E. Tekkaya

Navigation of robotics platform using advanced image processing navigation methods

SNIP: Smile - neutral facial display intensity predictor

K. Nurzynska \& B. Smolka

Author index 